\title{
A Problem-based Learning Approach and Its Effects on the Writing Performance of Nigerian Undergraduates
}

\author{
Muhammad Mukhtar Aliyu', Yong Mei Fung', Sabariah Md. Rashid², Vahid Nimehchisalem ${ }^{3}$ \\ ${ }^{1}$ Department of English and Literary Studies Bauchi State University, Nigeria \\ ${ }^{2}$ Department of English, Faculty of Modern Languages and Communication, Universiti Putra Malaysia, Malaysia \\ Email corresponding authors: mamukhtar@basug.edu.ng
}

\section{How to cite this paper:}

Aliyu, M. M., Fung, Y. M., Rashid, S. M., \& Nimehchisalem, V. (2020). A Problem-based Learning Approach and Its Effects on the Writing Performance of Nigerian Undergraduates. International Journal of Language Teaching and Education,4(1), 23-35. https://doi.org/10.22437/ijolte.v4i1.8750

Received: February 14, 2020

Accepted: May o2, 2020

Published: July 31, 2020

This work is licensed under the Creative Commons Attribution International License (CC BY 4.0). http://creativecommons. org/licenses/by/4.0/ (c) (†)

\begin{abstract}
Writing is considered as an important but a difficult language skill for undergraduates. To develop writing skills, undergraduates need to be given the opportunity to interact with and help one another in the writing process. They also need to be supported by teachers in the process. However, most of the traditional teaching methods adopted by writing instructors in Nigeria do not allow students to interact in the learning process. In this light, this study investigates the effects of a problem-based learning approach (PBL) on the writing performance of Nigerian undergraduates. The study employed a pre- and- post-treatment quasi-experimental research design. The participants $(n=18)$ involved in the study were an intact class of second-year students taking English composition course and two tutors in a college in North-eastern Nigeria. The study was conducted over a period of 12 weeks. To determine the effects of PBL on the participants' writing performance, a rating scale was used to rate the content, organisation, vocabulary, grammar and mechanical accuracy of the pre- and posttreatment writing scripts. A paired-sample t-test analysis was run to compare the mean scores of the undergraduates' pre- and post-treatment writing. The results showed significant improvements in all the components (content, organisation, vocabulary, language use and mechanics) of the participants' writing in the post-treatment. The paper concludes with a discussion on the pedagogical and theoretical contributions of the findings. It provides writing instructors with a student-centred approach that would help to develop their students' writing skills.
\end{abstract}

\section{Subject Areas \\ Second Language Writing}

Keywords

ESL classroom, PBL, writing instruction, Nigeria 


\section{Introduction}

In Nigeria, English is used as a second language, the official language as well as the medium of instruction at all levels of education (primary, secondary and tertiary levels). Proficiency in the English language has been one of the determining factors for the chances of pursuing higher education and higher skilled jobs in the country. This is because a credit pass in English is a requirement for admission to all universities in Nigeria (Tikolo, 2012). From the perspective of the labour market after graduation, proficiency in English remains one of the most important skills required for employment in the country (Dabalen, Oni, \&Adekola, 2000). Thus, this necessitates the need for Nigerian undergraduates to be proficient in writing in English.

However, researchers have shown that many Nigerian undergraduates have various difficulties with their writing in English which reduce their writing quality. Various problems have been identified in the writing of Nigerian undergraduates. For instance, Theodore (2013) pointed out that the students lack good communicative and imaginative skills to express their ideas clearly to the readers. In addition, they lack ideas relevant to a writing topic, and they commit grammatical and mechanical errors (Bodunde \& Sotiloye, 2013).

These problems are attributed to various factors, which include the instructional methods through which the students learn writing (Oluwale, 2008). Research has shown that most of the instructional approaches used by Nigerian instructors in writing are product-based, where much emphasis is given to the written product, rather than what the students think or do while writing (Muodumogu \& Unwaha, 2013). In most cases, students are only given topics and then asked to produce essays on their own. In some other cases, they are provided with basic information about the topic, such as theme, structure, tone and other aspects of style and asked to write an essay (Omachonu, 2003). The written output is assessed thereafter emphasizing mostly the mechanical correctness of the writing. These methods make students view writing as a boring and difficult task. As a result, the students make little or no improvement in their writing (Obi-Okoye, 2004).

The methods are adopted by the Nigerian instructors due to some factors which include limited access to new approaches and research findings that have been proven effective in improving learners' writing skills. Another factor is the large number of students in classrooms (Babalola, 2011). This shows the need to adopt new approaches to teaching and learning of writing that would help both students and instructors in the teaching and learning process. With this in mind, the researchers investigated the effects of the problem-based learning approach (PBL) on the writing performance of Nigerian undergraduates in order to provide an effective method of teaching and learning writing in Nigeria.

The rationale behind using the PBL approach in the writing instruction is that researchers describe writing as a complex process which involves cognitive, metacognitive (Devine, Railey \& Boshoff, 1993) and social factors (McLane, 1990). For students to develop their writing skills, these factors need to be taken into consideration. Further, scholars have suggested that in order to develop students' writing skills, instructors should adopt approaches that engage students in their writing process and allow them to work together, supporting one another to learn strategies for planning, revising, and editing their writing (Graham \& Harris 2009; Xiao 2007). In the PBL approach, these factors are considered in the learning process.

PBL is a student-centred approach based on the constructivist theory which contextualises learning in a real-life situation and allows learners to work collaboratively in order to learn (Jonassen, 1997; 
Mardziah, 1998). It focuses on assisting students to develop flexible knowledge, effective problem-solving skills, intrinsic motivation, collaborative and self-directed learning (Barrows, 1996).

In the PBL approach, subject content is given to students as an ill-structured problem, which is a problem related to their real-life situation and is complex enough to stimulate their thinking (Jonassen, 1997). The descriptions of the ill-structured problem are not clearly defined and the information needed to solve it is not contained in its problem statement. Thus, there may be various solutions to the problem based on students' perceptions and interpretations of the nature of the problem (Shin, Jonassen, \& McGee, 2003). The ill-structured problem stimulates the students to think, interact, discover the solutions to the problem, and eventually acquire the knowledge and skills required for the course (Jonassen, 2000). Using the ill-structured problem in PBL creates cognitive conflict among the students, which promotes their higher order and critical thinking (Hmelo-Silver, 2004; Savery \& Duffy, 2001) and develops their cognitive skills.

In addition, the students take the major responsibility for their learning. They work in small groups discussing an ill-structured problem, decide and discover for themselves what they will learn and how they will learn (Mardziah H. Abdullah, 1998). Through the discussion, the students share expertise and support one another via monitoring and assessing their own performance and that of their peers. They also determine where and how to find the appropriate resources for the information needed in order to provide the viable solutions, such as textbooks, library and online material. The problem-solving activities stimulate discussions among group members and keep them motivated to learn more about the subject. This helps the students to develop their writing skills as well as social and other related skills.

Instructors, on the other hand, take the role of facilitators that guide students' learning. They support and guide the students to focus on the learning objectives. They create a suitable learning environment and monitor the learning process (Hmelo-silver \& Barrows, 2006) through stimulating the students' abilities to analyse information. Through the facilitation, the students develop their learning skills. Furthermore, the facilitators assist the students in identifying appropriate resources to obtain the required information and apply new information to their problem-solving work. The facilitators also help the students to summarise what has been learned and evaluate peers and themselves. As the students more gain experiences, the facilitators withdraw their supports and intervene only when it is necessary. Integrating the PBL approach into the writing instruction provides opportunities for students to be actively engaged in the writing process.

In recent decades, many researchers have explored the effectiveness of the PBL approach in various disciplines and have reported its positive effect on students' learning skills, such as acquisition and retention of content knowledge, development of thinking skills (Hande, Mohammed \& Komattil, 2014), attitude (Batdi, 2014), and other soft skills (Deep, Salleh, \& Othman 2016). However, in the ESL classroom, few studies have explored the usefulness of the PBL approach. Mardziah H. Abdullah and Tan (2008) carried out a study in an online ESL context in Malaysia using PBL and revealed its linguistic and affective benefits to the ESL classroom. It provided a context which stimulated communication among students and caused them to generate extensive discussions on various topics. Through the discussions, the students acquired problem-solving skills, self-directed learning skills and other aspects of language like grammar. Similarly, Norzaini Azman and Shin (2012) conducted a study in a university in Malaysia and found that the PBL approach developed learners' speaking skills. Othman and Ismail Ahmad Shah (2013) investigated the effects of the PBL approach on students' acquisition of course content and writing 
performance. Their findings showed the effectiveness of the approach on the students' acquisition of the course content and writing performance particularly in terms of supporting their argument in the writing. The literature shows that these studies carried out with ESL learners did not involve the writing classrooms. This is also true in the Nigerian context, whereby the literature did not reveal any study that has employed the PBL approach in the Nigerian ESL classroom.

\section{Purpose of the Study}

The present study intends to investigate the effects of the PBL approach in improving the writing performance of Nigerian undergraduates. Findings of this study would shed light on the suitability of the PBL approach in the Nigerian ESL writing classroom, which in turn could be used by writing instructors to develop their students' writing skills. The following research question is formulated to guide the study: What is the effect of the PBL approach on the various aspects of writing performance (content, organisation, vocabulary, grammar and mechanical accuracy) of Nigerian undergraduates?

\section{Method}

\subsection{Research Design}

The study adopted a pre- and post-treatment quasi-experimental research design. The data were collected for the period of 12 weeks. The PBL treatment of the study was carried out for seven weeks. In the first three weeks, the participants collaboratively discussed one ill-structured problem and provided viable solutions to the problem in their writing. Through the discussion, the participants brainstormed and generated ideas related to the ill-structured problems. From the ideas, they identified issues which they needed more information about. They shared the issues among them and identified resources to look up or consult during self-directed learning. In the fourth week, a debriefing session was conducted with the tutor to discuss writing and PBL related issues. In weeks 5-7, the participants worked on another illstructured problem following the same steps as in weeks 1 to 3 .

\subsection{Participants}

The participants of the study consisted of 18 second-year students in an intact class of Introduction to English Composition course in a college in North-eastern Nigeria. They were of mixed gender with age ranged from 24 to 38 years old. The participants were divided into three groups of six participants each. All of them had also completed and passed the Introduction to Composition I course. For the purpose of this study, the participants were assigned into their respective groups using systematic random sampling method. The participants were numbered based on their sitting arrangement.

\subsection{Material and Instruments}

Writing activity is the main material used to collect the data of this study. The activities were given in the form of ill-structured problems. One ill-structured problem was given for each of the pre- and posttreatment activities and all the students were asked to write individually and propose viable solutions to the problems. For the pre- treatment, the ill-structured problem given was a problem related to students' 
accommodation which had been under renovation for about three semesters. As for the post-treatment, the ill-structured problem was about a rule passed by their institution regarding admission into the Department of English.

The other two ill-structured problems were given during the PBL treatment. The first ill-structured problem was about terrorism in Northern Nigeria which involved students. The second ill-structured problem was on Nigerian undergraduates' excessive engagement with social media, which negatively affected their academic performance (see Appendix A for details on the ill-structured problems). The participants were asked to collaboratively discuss following the PBL steps and propose viable and plausible solutions to the problems. They were given three weeks to work on each problem and come up with proposed solutions.

All the ill-structured problems were validated by a panel of experts (Creswell, 2012) to ensure that the problems are related to the students' real-life and are complex enough to stimulate their learning. The panel comprised three experts who were researchers and ESL instructors in a local university in Malaysia. They all had $\mathrm{PhD}$ qualifications with more than 20 years of teaching experience in tertiary institutions. In addition, a pilot study was conducted to identify any possible problems related to the ill-structured problems.

Jacobs, Zinkgraf, Wormuth, Hartfiel and Hughey's (1981) ESL Composition Profile was adapted to rate the participants' writing. The scale has five components with a total score of 100: content 30, organisation 20, grammar 25, vocabulary 20 and mechanics 5 . Each component comprises the following four categories: excellent to very good, good to average, fair to poor, and very poor (see Appendix B for the description of the components).

All the participants' scripts were rated by two Nigerian English language instructors experienced in rating students' writing. One of the instructors had a $\mathrm{PhD}$ in English language and taught English in tertiary institutions for 24 years. The second instructor held an MA degree with 26 years of experience teaching English in tertiary institutions. The raters were trained on how to use the writing scale before marking the participants' pre- and post-treatment writing scripts.

\subsection{Data Collection Procedures}

As mentioned previously, the data of the study were collected for a period of 12 weeks. In the first week, the researchers administered a pre-treatment writing activity. In the second week, the researchers explained the basic concepts of the PBL approach to the participants to enable them to participate effectively. They also explained the roles and responsibilities of the tutors and those of the participants. The participants were grouped into three groups of six participants each, using systematic random sampling. Thereafter, the researchers showed the class how PBL is practically carried out. Then each group was asked to carry out the processes.

In week 3, the PBL treatment was administered to the participants. An ill-structured problem was presented to the groups and they were asked to propose viable (written) solutions following Savery and Duffy (1995) model of PBL. The stages are as follows:

1. Generate working ideas or possible solutions;

2. Identify available information related to the problem;

3. Identify learning issues (things about which they need to find more information);

4. Identify resources to look up or consult; 
5. Assign tasks to the various group members (i.e., share the learning issues);

6. Gather information (conduct self-directed learning); and

7. Propose solution(s).

The participants were able to cover five steps; they were able to generate ideas (possible causes and solutions related to the ill-structured problem) by brainstorming. They also identified learning issues and the resources to look up or consult for the needed information. Finally, they shared the learning issues among themselves to come up with findings in the subsequent meeting. In the second meeting of the third week, these processes were repeated to enable the participants to get the concept clearly.

In Week 4, every group member presented his/her findings to their respective groups. Every group discussed its findings and criticised the source of the information. They further identified more learning issues on some items with which they were not satisfied, and finally drafted proposed solutions to the ill-structured problem. In Week 5, every group reviewed, edited their draft and redrafted the solutions. Finally, every group presented its findings to the class. After taking corrections and observations from peers and tutors, every group made the corrections and submitted the proposed solutions to the researchers. In Week 6, there was a debriefing session where issues related to the PBL approach and writing were discussed and clarified by the researchers.

In Week 7, the second ill-structured problem was presented to the participants to propose possible solutions. The same PBL activities of Weeks 3 to 5 were repeated in Weeks 7-9. Throughout the PBL process, the first author and the course lecturer were facilitators who helped the participants through open-ended questioning. Another debriefing session was conducted in week 10 . In week 11, the posttreatment activities were administered. Finally, the participants were interviewed in the last week.

\subsection{Data Analysis}

Before running any analysis, an inter-rater reliability analysis was conducted to determine the level of consistency between the scores of the raters using intra-class correlation coefficient (ICC). From the analysis, a highly significant agreement was found between the scores of the two raters $(\mathrm{F}=8.544, \mathrm{p}=.000$, $95 \%$ CI [.760 - .951]). The average measure ICC was .883. This means that there is $78 \%$ of agreement between the two raters. The result indicates a strong agreement between the raters as the intra-class correlation coefficient of 0.6 and above is considered acceptable (Landis \& Koch, 1977). The result is presented in Table 1.

Table 1. Intra-class correlation coefficient

\begin{tabular}{|c|c|c|c|c|c|c|c|}
\hline \multirow{3}{*}{$\begin{array}{l}\text { Average } \\
\text { Measures }\end{array}$} & \multicolumn{3}{|c|}{$\begin{array}{l}\text { 95\% Confidence } \\
\text { Interval }\end{array}$} & \multirow{2}{*}{ F-Value } & \multirow{2}{*}{ Df1 } & \multirow{2}{*}{ Df2 } & \multirow{2}{*}{ Sig. } \\
\hline & Correlation & Lower Bound & Upper Bound & & & & \\
\hline & .883 & .760 & .951 & 8.544 & 17 & 51 & .000 \\
\hline
\end{tabular}

Following the reliability analysis, a normality test was run on the pre- and post-treatment writing scores to ensure that the data meet the requirement for parametric analysis. The skewness values ranged between-.243 and .780 while the kurtosis values ranged between -.445 and 1.730. Based on the literature, 
skewness and kurtosis values between \pm 2 are acceptable (George \& Mallery, 2003). Thus, the results of the normality tests indicated that the assumption of normality was met. Therefore, to determine the effects of the PBL approach on the participants' writing, the scores of the 18 pre-treatment scripts were compared with the scores of the 18 post-treatment scripts using a paired-sample t-test with the significant level set at $\alpha=.05$.

\section{Results and Discussion}

The results of the descriptive statistics showed that the mean of the total score for the pre-treatment writing was $M=57.16$ and it increased in the post-treatment to $M=65.86$. The result further showed that the mean scores for each of the components increased in the post-treatment. Table 2 presents the results of the descriptive statistics.

Table 2. Descriptive statistics of the pre-and post-treatment writing scores $(n=18)$

\begin{tabular}{lccc}
\hline \multicolumn{1}{c}{ Treatment } & Mean & SD & Std. Error Mean \\
\hline Pre-treatment Content & 18.33 & 1.72 & .406 \\
Post-treatment Content & 21.33 & 1.70 & .402 \\
Pre-treatment Organisation & 12.00 & 1.15 & .271 \\
Post-treatmentOrganisation & 14.08 & 1.19 & .280 \\
Pre-treatment Vocabulary & 12.19 & 1.17 & .277 \\
Post-treatment Vocabulary & 13.50 & 1.40 & .330 \\
Pre-treatment Language Use & 12.36 & 1.73 & .409 \\
Post-treatment Language Use & 13.88 & 2.57 & .607 \\
Pre-treatment Mechanics & 2.277 & 0.39 & .092 \\
Post-treatment Mechanics & 3.055 & 0.53 & .127 \\
\hline Pre-treatment Overall & 57.16 & 4.03 & .950 \\
\hline Post-treatment Overall & 65.86 & 5.62 & 1.325 \\
\hline
\end{tabular}

Based on the writing scale, the results presented above show that the content of the participants' writing in the pre-treatment had limited knowledge of an ill-structured problem, minimal viable and plausible solutions to the ill-structured problem and inadequate development of the thesis. As an illustration, an example is given in Excerpt A written by Habib (mistakes are underlined). The excerpt is selected as an example because it is representative of the rest of the participants. Most of the participants made the same types of mistakes. In the excerpt, Habib proposed viable solutions to the students' accommodation problem due to the slow progress of their hostel renovation. Habib offered only one viable solution to the problem. However, he did not clearly explain and support it with relevant examples on how it is applied in other institutions. All other solutions proposed were only restatements of what was known, what was being practiced in the school as could be seen in the second and third paragraphs. This shows Habib's insufficient knowledge of the ill-structured problem, inability to provide substantively viable solutions to the problem and lack of thesis development of the writing. 


\section{Excerpt A}

In an Institution Hostel is an inexpensive supervised lodging, especially for youth on bicycling trip and for student lodging. This are some of the possible solutions of lack of students' accommodation in the campus because the hostels are under renovation. First of all the university is expected to provide accommodation for students outside the school that is, to look for an estate nearby, that may make transportation easier for them, and also the students should continues to pay their normal accommodation fees as usual.

Secondly, if the nearby estate or building that can accommodate the students cannot be found, then the school should found it even if it is far away from the school and they have to provide means of transportation to make it easier _ the while going to the main campus. For example, here in College of Education Azare, the number of students is very large, that the hostels cannot accommodate the students in the campus. The school decided to rent another building outside the campus, and it is far from the main campus. The school provides buses for the students transportation at low cost.

Thirdly, the students can group themselves to rent a low cost houses nearby in order to reduce the cost of payment and they can even trek to the main campus on time. In conclusion, if certain majors should be taken, I hope there will be no more any problem of accommodation or hostels to the students. In terms of organisation, the writing of the participants in the pre-treatment was nonfluent and disconnected solutions. The results also showed that the writing lacked logical sequencing and development of the viable solutions provided by the participants. For instance, Excerpt A lacked logical presentation of ideas as the only viable solution offered by Habib appeared almost at the end of the writing. In addition to the organisation, the results show that the pre-treatment writing of the participants displayed a limited range of vocabulary related to an ill-structured problem. The writing also contained frequent errors of word form, choice and usage that obscure meaning. These could also be seen in Excerpt A. There are a limited range and inappropriate use of vocabulary. For example, the use of the words 'inexpensive supervised' and 'lodging' does not give a clear definition of hostels. In addition, the use of the words 'estate' and 'building' repetitively to refer to accommodation also shows an inappropriate choice of word.

As for language use, the results show that the pre-treatment writing of the participants has a major problem in complex and simple sentence structures. It also has frequent errors of agreement, tense, number, negation, word order, articles, pronouns, prepositions and fragments which obscure meaning. In Excerpt A there is an error of agreement "this are" in the second paragraph. Another example is the wrong form of verb in "should continues" in the second paragraph. Finally, the results indicate that the writing dominated by errors of spellings, punctuations, capitalisations and paragraphing. For example, the use of capital letters in the words institution and hostel. The second sentence of the second paragraph was also not properly punctuated and that affects the intended meaning. Also 'measures' is wrongly spelled as 'majors' in the last sentence of the Excerpt.

For the post-treatment writing, the results showed some improvements in the content of participants' writing. It indicated that the participants had some knowledge of the ill-structured problem and adequate range of viable and plausible solutions to the problem. The comparison of samples written by the participants before and after the treatment shows despite its limited development, the thesis was mostly relevant to the problem in the post-treatment writing. These are shown in Excerpt B also written by Habib. The excerpt provided viable solutions to the problem regarding the students' admission requirements into the Department of English at the participants' institution. The ideas of the excerpt were 
clearer and more developed compared to the pre-treatment ones. For example, Habib provided three viable solutions to the ill-structured problem. He also explained and gave examples for how the solutions should be implemented. For instance, in the second paragraph, Habib suggested that a basic remedial programme for Literature in English should be organised by the institution. He also provided justification to support his claim by referring to other universities that used the same remedy.

\section{Excerpt B}

It is however clear that, this policy is inappropriate and instead, we suggest the following ways as solutions to this problem.

First, Department of English should organise basic program in literature in English to cover up the deficient in the requirement. This is referenced to what I know of the universities of Kano (BUK) and Sokoto (UDUS) where deficiency (ies) in English and/or Mathematics is remedied through the basic program by which a minimum of passing marks of $40 \%$ is required to qualify a candidate to read either of the two courses. This should be emulated by my department in literature in English program.

Second, higher institutions departments particularly English should liaise with the curriculum planners to put and mandate the study of English or literature in English from SS I of secondary school. This will complement the department's need as substantial to the students (applicants) even before they apply for admission.

Lastly, the department should consider the general English rather than an aspect (i e literature) for admission unless if the applicant wishes to read (study) literature. If not, it is inappropriate and the department should stop misappropriating the requirement for studying English.

The results further show that the organisation of the solutions is more logical in the post-treatment script. For example, compared to Excerpt A, Excerpt B is more organised, in which cohesive makers first, second and third have been used to indicate the transition of ideas and to signal the viability of the solutions. In Excerpt B, there is also an adequate range of vocabulary related to an ill-structured problem. Although there are occasional errors of word form, choice and usage, meaning is not obscured. Varieties of vocabulary items have been used. For example, the word policy is used for the rule. In addition, there are frequent errors of agreement, tense, number, negation, word order, articles, pronouns, prepositions. However, the meaning is not obscured. There are less grammatical errors in Excerpt B than in Excerpt A of the pre-treatment writing scripts. Finally, there are some improvements in the mechanics. Despite the frequent errors in spellings, punctuation, capitalisation and paragraphing, the meaning of the writing is not obscured. There are also no serious spelling or punctuation mistakes in Excerpt B.

From the results of the paired-sample t-test, a significant mean difference is obtained in the overall scores of the participants' writing before and after the PBL treatment $(t=9.09, p=.000)$. This suggests the positive effects of the PBL approach on the participants writing performance. The results further showed significant improvements in all the components of the participants' writing in the post-treatment writing: content $(t=13.78, p=.000)$, organisation $(t=8.93, p=.000)$, vocabulary $(t=3.31, p=.004)$, language use $(t=$ $3.38, \mathrm{p}=.004)$ and mechanics $(\mathrm{t}=6.01, \mathrm{p}=.000)$. This also shows the positive effect of the PBL approach on each of the components of the participants' writing. The summary of the results of the paired-sample $t-$ test is presented in Table 3. 
Muhammad Mukhtar Aliyu, Yong Mei Fung, Sabariah Md Rashid, Vahid Nimehchisalem

Table 3. Comparison of pre-and post-treatment writing scores $(n=18)$

\begin{tabular}{|c|c|c|c|c|c|c|c|c|}
\hline \multirow[t]{2}{*}{ Components } & \multirow[t]{2}{*}{ Mean } & \multirow[t]{2}{*}{ SD } & \multirow{2}{*}{$\begin{array}{l}\text { Std. Er } \\
\text { Mean }\end{array}$} & \multicolumn{2}{|c|}{$\begin{array}{l}\text { 95\% Confidence } \\
\text { Interval of the } \\
\text { Difference }\end{array}$} & \multirow[t]{2}{*}{ t-value } & \multirow[t]{2}{*}{ df } & \multirow[t]{2}{*}{ Sig. (2 tailed) } \\
\hline & & & & Lower & Upper & & & \\
\hline Content & 3.000 & 0.92 & 0.217 & 2.540 & 3.459 & 13.78 & 17 & .000 \\
\hline Organisation & 2.083 & 0.98 & 0.233 & 1.591 & 2.575 & 8.93 & 17 & .000 \\
\hline Vocabulary & 1.305 & 1.67 & 0.394 & 0.473 & 2.137 & 3.31 & 17 & .004 \\
\hline Language Use & 1.527 & 1.91 & 0.450 & 0.576 & 2.479 & 3.38 & 17 & .004 \\
\hline Mechanics & 0.777 & 0.54 & 0.129 & 0.505 & 1.050 & 6.01 & 17 & .000 \\
\hline Overall & 8.694 & 4.05 & 0.955 & 6.677 & 10.711 & 9.09 & 17 & .000 \\
\hline
\end{tabular}

To answer the research question on the effect of PBL on the participants' writing performance, it could be seen from the statistical analysis that the PBL approach has significant effects on the participants' writing performance. The significant improvements were observed in the content, organisation, vocabulary, language use and mechanics of the participants' writing. The findings confirm the assumptions of the study that the PBL would develop the students' writing performance based on the view of the constructivist theory of learning which suggests that learners build new knowledge from previous one through social interaction.

Based on the results of the study, the findings show that PBL encouraged the students to generate ideas relevant to the given topic (ill-structured problem) through their interactions. This enabled them to develop the content of their writing. The interactions and the tutor facilitation also enabled the students to logically organise their ideas in the writing. These findings are in line with the findings of previous studies which revealed significant positive effects of PBL on students' learning performance. Hande et al. (2014) as well as Tarmizi and Bayat (2010) found out that PBL enables students to acquire knowledge of the subject. The findings are also similar to those of Othman and Ismail Ahmad Shah (2013) who observed that PBL allowed students to enrich the content of their writing and support their argument critically as the result of extensive reading and critical discussions the students had during the PBL activities.

Furthermore, the significant improvements observed in the language use, vocabulary and mechanics of the participants' post-treatment writing are indications of the usefulness of PBL. This shows that the ill-structured problems, the peer collaboration and the tutor facilitation during the PBL process encouraged the participants to exchange and share their knowledge on mechanics, vocabulary and the language use. It is not surprising that the participants improved their writing performance because the illstructured problems were related to their real-lives; they all had first-hand information about these problems. It was easier for them to generate substantial ideas. Another reason is that after writing first draft of their essays during the PBL process, a member in each group read the essay aloud among his/her group members. This allowed each group to deliberate on the content, organisation, vocabulary, language use and mechanics of the essays and make changes to improve them.

In addition, the participants also received feedback from the tutors which also helped them to improve their writing. These findings also agree with those of previous studies, which revealed that frequent and timely feedback motivate students and allow them to make necessary changes to their final project parts and improve performance in the PBL learning environment (Webb \& Moallem, 2016). Other 
studies also showed that PBL provided students with an opportunity to learn new words and grammatical rules. For instance, Mardziah H. Abdullah and Tan (2008) revealed that the PBL approach provided the students with a real context that stimulated discussions on various topics, both academic and social, thereby allowing them to learn new vocabulary and develop their knowledge of grammatical rules. The findings also support the suggestions made by Graham and Harris (2009) on the need to engage and support students in the writing process in order to improve their writing skills.

\section{Conclusion}

Based on the findings, it can be concluded that the PBL approach has significant effects on the overall writing performance of the participants. Theoretically, the study adds to the previous attempts to extend PBL from its original use in the medical classroom context to the ESL classroom, especially, writing. The findings support the constructivist's theory of learning. The study shows that engaging students to discuss and write collaboratively on an ill-structured problem under a tutor's guidance, as in the PBL context, would significantly improve content, organisation, language use, vocabulary and mechanics of the students' writing.

From the pedagogical perspective, the study provides empirical evidence on the benefits of PBL in writing classrooms, which confirms the assertion made by Graham and Harris (2009) on the need to engage and support students in the writing process for improved performance. Furthermore, it is previously mentioned that the instructors lack awareness or absence of new approaches and research findings that have been proven effective in developing students' writing skills (Babalola, 2011). Therefore, the study provides writing instructors, particularly in the Nigerian context, with a studentcentred approach that would allow them to engage, support and monitor their students in the writing process. This would eventually help to develop the students' writing skills. For the students, the findings of this research revealed that the PBL approach would improve their thinking and communicative skills while expressing their ideas to readers in writing, which according to Theodore (2013) many Nigerian undergraduates lack. Also, the students would minimise their grammatical and mechanical mistakes, pointed out by Bodunde and Sotiloye (2013).

\section{Recommendation}

This study was carried out for only one semester with second-year students. Thus, further studies should administer the PBL treatment for a longer period. For instance, the PBL intervention could be administered for two consecutive semesters in either second or third year of the undergraduate programme. Alternatively, the intervention could be administered for one semester in the second year and another semester in the third year of the programme.

Another limitation of the study is that there is no control group. Future studies should use more students or larger groups of students particularly in public universities in Nigeria, where there are many students in a class and can be divided into control and experimental groups. In addition, the study focuses on writing only which is not the only problem faced by Nigerian ESL undergraduates. Further studies should investigate the effects of the PBL approach in developing other language skills such as listening, reading and speaking. 
Muhammad Mukhtar Aliyu, Yong Mei Fung, Sabariah Md Rashid, Vahid Nimehchisalem

\section{References}

Babalola, H. A. L. (2012). Effects of process-genre based approach on the written English performance of computer science students in a Nigerian polytechnic. Journal of Education and Practice, 3(6), 1-6.

Barrows, H. S. (1996). Problem-based learning in medicine and beyond: A brief overview. In L. Wilkerson $\&$ W. H. Gijselaers (Eds.), Bringing problem-based learning to higher education: Theory and practice (pp. 3-12). San Francisco: Jossey-Bass.

Barrows, H. S. \& Tamblyn, R.M. (1980). Problem-based learning: An approach to medical education. Springer Publishing, New York, N.Y.

Batdi, V. (2014). The effects of a problem-based learning approach on students' attitude levels: A metaanalysis. Educational Research and Reviews, 9(9), 272-276.

Bakare, T. V. (2011). The use of teaching methods and styles in the Nigerian university system:The curriculum and policy implications for change. Journal of International Education Research, 7(1). 89-99.

Bodunde, H. A., \& Sotiloye, B. S. (2013). A critique of undergraduate students' writing skill in an ESL setting: Samples from the Federal University of Agriculture, Abeokuta, Nigeria. World Journal of English Language, 3(2), 10-21.

Cohen, J. (1988). Statistical power analysis for the behavioural sciences (2nd Ed.). Hillsdale, NJ: Lawrence Earlbaum Associates.

Creswell, J. W. (2012). Educational research: Planning, conducting, and evaluating quantitative and qualitative research. 4th edition, Upper Saddle River, NJ, Pearson Merrill Prentice Hall.

Dabalen, A., Oni, B., \&Adekola, O. A. (2000). Labour market prospects for university graduates in Nigeria (World Bank Report). Nigeria University System Innovation Project. Retrieved from https://pdfs.semanticscholar.org/27e4/81c7de393465f212bb6331b41943d7f94599.pdf

Deep, S., Salleh, B. M., \& Othman, H. (2016). Exploring the role of problem-based learning in developing conflict resolving and other soft skills: A quasi-experimental study. International Review of Management and Marketing, 6(4), 738-748.

Devine, J., Railey, K., \& Boshoff, P. (1993). The implication of cognitive models in L1 and L2 writing. Journal of Second Language Writing, 2(3), 303-225.

Dods, R. (1997). An action research study of the effectiveness of problem-based learning in promoting the acquisition and retention of knowledge. Journal for the Education of the Gifted, 20(4), 423-37.

George, D., \&Mallery, P. (2003). SPSS for windows tep by step: A simple guide and reference.11.0 update (4thed.). Boston: Allyn\& Bacon.

Graham, S., \& Harris, K. R. (2009). Evidence-based writing practices: Drawing recommendations from multiple sources. British Journal of Educational Psychology 2(6), 95-111.

Hmelo-silver, C. E., \& Barrows, H. S. (2006). Goals and strategies of a problem-based learning facilitator, Interdisciplinary Journal of Problem-based Learning, 1(1), 21-39.

Hmelo-Silver, C. E. (2004). Problem-based learning: what and how do students learn? Educational Psychology Review, 16(3), 235-266.

Jacobs, H., Zinkgraf, S., Wormuth, D., Hartfiel, V., \& Hughey, J. (1981). Testing ESL composition: A practical approach. Rowley, MA: Newbury House.

Jonassen, D. H. (1997). Instructional design models for well-structured and ill-structured problemsolving learning outcomes. Educational Technology Research and Development, 45(1), 65-94.

Jonassen, D. H. (2000). Toward a design theory of problem solving. Educational Technology Research and Development, 48(4), 63-85.

Hande, S., Mohammed, C. A., \& Komattil, R. (2014). Acquisition of knowledge, generic skills and attitudes through problem-based learning: Student perspectives in a hybrid curriculum, Journal of Taibah University Medical School. 10(1), 21-25.

Hosseini Bidokht, M., \& Assareh, a. (2011). Life-long learners through problem-based and self-directed learning. Procedia Computer Science, 3(2011), 1446-1453.

Landis J. R., \& Koch, G. G. (1977). The measurement of observer agreement for categorical data. Biometrics. 33(1), 159-174.

Mardziah H. Abdullah. (1998). Problem-based learning in language instruction : A constructivist model. ERIC Clearinghouse on Reading English and Communication Bloomington, 1-6.

Mardziah H. Abdullah., \&Tan, B. H. (2008). Wired together: Collaborative problem-pased language learning in an online forum. Malaysia Journal of ELT Research 4(1), 54-71. 
McLane, J. B. (1990).Writing as a social process, In L. C. Moll (Ed.), Vygotsky and education: Instructional implication of sociohistorical psychology (pp. 304-318). New York: Cambridge University Press.

Muodumogu, C. A. \& Unwaha, C. O. (2013). Improving students' achievement in essay writing: What will be the impact of mini-lesson strategy? Global Advanced Research Journal of Arts and Humanities (GARJAH), 2(6), 111-120.

Ngadda, Z. Y., \&Nwoke, A. (2014). An analytical study of errors in the written English of undergraduate engineering students, ATBU a case study. Journal of Education and Practice, 5(38) 8-16.

NorzainiAzman, \& Shin, L. K. (2012). Problem-based learning in English for a second language classroom: Students' perspectives. The International Journal of Learning, 18(6), 109-126.

Obi-Okoye, A. F. (2004). Advanced English composition: The writing process approach. Onitsha: Ganja Books.

Olusoji, O. A. (2013). Effects of bilingualism on the essays of Yoruba/English bilinguals. European Journal of Arts and Humanities, 1(1), 36-47.

Omachonu, G. S. (2003). Effective writing skills. Nsukka: A.P. Express Publishers Limited, Nigeria.

Othman, N., \& Ismail Ahmad Shah, M. (2013). Problem-based learning in the English language classroom. English Language Teaching, 6(3), 125-134.

Savery, J. R. (2006). Overview of problem-based learning: Definitions and distinctions. Interdisciplinary Journal of Problem-Based Learning1(1), 9-20.

Savery, J. R., \& Duffy T. M. (1996). Problem based learning: An instructional model and its constructivist framework. In B. G. Wilson (Ed.), Constructivist learning environments: Case studies in instructional design (pp.135-150). Englewood Cliffs, NJ: Educational Technology.

Savin-Baden, M. (2000). Problem-based learning in higher education: Untold stories. Buckingham: Open University Press.

Savery, J. R., \& Duffy, T. M. (2001). Problem based learning: An instructional model and its constructivist framework. CRLT Technical Report No. 16-01, Center for Research on Learning and Technology, Indiana University, June 2001.

Shin, N., Jonassen, D. H., \& McGee, S. (2003). Predictors of well-structured and ill-structured problem solving in an astronomy simulation. Journal of Research in Science Teaching, 40(1), 6-33.

Tarmizi, R. A., \& Bayat, S. (2010). Effects of problem-based learning approach in learning of statistics among university students. Procedia-Social and Behavioural Sciences, 8(2010), 384-392.

Theodore, I. (2013). An appraisal of students' errors in English compositions : Implications for the open and distance learning classroom. International Journal of English and Literature, 4(10), 516-522.

Tikolo, O. (2012). English language incompetency amongst senior secondary school graduates in Nigeria: Education policy analysis and research utilization in comparative perspective. Harvard Graduate School of Education. Retrieved from http://isites.harvard.edu/fs/docs/icb.topic1203150.files/Panel\%201\%20\%20Teaching\%20in\%20Tong ues/Olayide\%20Tikolo_Nigeria_English\%20Language\%20Incompetency_Final.pdf

Webb, A., \& Moallem, M. (2016). Feed dback and feed-forward for promoting problem-based learning in online learning environments. Malaysian Journal of Learning and Instruction, 13(2), 1-41. 